\title{
EFEKTIVITAS PERANGKAT PEMBELAJARAN METODE OUTDOOR LEARNING UNTUK MENGEMBANGKAN ASPEK FISIK MOTORIK ANAK USIA DINI
}

\author{
Retno Dwi Astuti ${ }^{\text {a, } 1}$ \\ Universitas Islam Lamongan, Indonesia \\ e-mail : retnodwi.pasca@unisla.ac.id
}

\begin{tabular}{l}
\hline Informasi artikel \\
\hline Received : \\
Januari 19, 2020. \\
Revised : \\
Februari 13, 2020. \\
Publish :
\end{tabular}

Maret 09, 2020.

Kata kunci:

Efektivitas;

Perangkat

Pembelajaran;

Fisik Motorik

Keywords:

Effectiveness;

Learning Devices;

Physical Motoric;

\begin{abstract}
ABSTRAK
Penelitian ini bertujuan untuk mendeskripsikan efektivitas perangkat pembelajaran metode outdoor learning melalui miniatur kegiatan outbound untuk mengembangkan aspek fisik motorik anak usia dini. Desain pada penelitian ini adalah penelitian dan pengembangan (R\&D) menggunakan desain instructional development model 4D. Perangkat pembelajaran yang dikembangkan meliputi Progam Semester (Prosem), Rencana Pelaksanaan Pembelajaran Mingguan (RPPM) dan Rencana Pelaksanaan Pembelajaran Harian (RPPH). Hasil uji hipotesis dengan menggunakan rumus uji paired sampel t-test diperoleh thitung $=4.131$ dan ttabel $=2.045$. Karena thitung $>$ ttabel maka Ho ditolak dan $\mathrm{Ha}$ diterima. Berdasarkan hasil SPSS dan rumus manual uji paired sampel ttest menunjukkan bahwa Ha diterima, sehingga dapat dibuktikan bahwa ada perbedaan hasil belajar yang signifikan antara anak kelompok B sebelum menggunakan perangkat pembelajaran metode outdoor learning dengan anak kelompok B sesudah menggunakan perangkat pembelajaran metode outdoor learning.

ABSTRACT
This study aims to describe the effectiveness of the development of
outdoor learning method learning tools through miniature outbound
activities to develop the physical aspects of motoric early childhood. The
design of this research is research and development (R\&D). The
learning device development model used in this study is to use the $4 D$
instructional development design proposed by Thiagarajan which
consists of 4 stages of development namely Define, Design, Develop, and
Disseminate. The findings of this research and development are in the
form of learning tools that have previously been tested, evaluated, until
they meet the desired criteria. Learning tools developed include the
Semester Program (Prosem), Weekly Learning Implementation Plan
(RPPM) and Daily Learning Implementation Plan (RPPH). The results
of hypothesis testing using the paired sample t-test test formula obtained
tcount = 4.131 and ttable = 2.045. Because tcount> ttable, Ho was not
accepted and Ha was accepted. Based on SPSS results and paired
sample t-test test manualformula shows that Ha is accepted, so it can be
proven that there are significant differences in learning outcomes
between group B children before using an outdoor learning method with
group B children after using the outdoor learning method learning
device.
\end{abstract}

This work is licensed under a Creative Commons Attribution-ShareAlike 4.0 International License. Allows readers to read, download, copy, distribute, print, search, or link to the full texts of its articles and allow readers to use them for any other lawful purpose. 


\section{PENDAHULUAN}

Pendidikan anak usia dini sangatlah penting untuk dikembangkan dan distimulasi semua potensi yang ada pada diri anak, dimana anak usia dini berada dalam tahap pertumbuhan dan perkembangan yang sangat pesat, baik fisik maupun mental (Suyanto, 2005). Maka sangat tepat apabila anak usia dini disebut sebagai usia emas (golden age), dimana anak sangat berpotensi untuk mempelajari dan menirukan segala hal dengan cepat. Pada masa ini khususnya usia 4-6 tahun anak mengalami masa peka, anak sangat sensitif untuk menerima berbagai stimulus. Masa peka adalah masa terjadinya pematangan fungsi-fungsi fisik dan psikis yang siap merespon stimulasi yang diberikan oleh lingkungan sekitar anak.

Perkembangan fisik motorik sangat penting untuk dikembangkan pada anak usia dini karena anak usia 5-6 tahun sangat aktif bergerak untuk mengembangkan aspek fisik motorik dan memerlukan berbagai stimulasi positif dari semua pihak, baik dari orang tua, maupun gurunya. Hat tersebut sesuai dengan teori yang menekankan bahwa usia lahir sampai enam tahun merupakan masa peka, di mana dalam masa peka tersebut merupakan masa yang sangat baik dalam mengembangkan setiap potensi perkembangan yang dimiliki oleh anak, sehingga diperlukan kondisi dan stimulasi yang sesuai dengan kebutuhan pertumbuhan dan perkembangan anak tersebut (Husamah, 2013). Untuk itu, pembelajaran dengan metode outdoor learning sangat cocok untuk diterapkan pada anak usia dini. Metode outdoor Learning akan semakin memperkaya wawasan dan pengetahuan anak serta mengembangkan fisik motorik karena anak belajar tidak tebatas oleh empat dinding kelas dan dapat berinteraksi langsung dengan lingkungan sekitar dan teman sebayanya. 
Dalam mengembangkan aspek perkembangan fisik motorik anak, miniatur kegiatan outbound sangat menarik bagi anak, karena dengan kegiatan tersebut anak akan melihat sesuatu yang lain dari biasanya ketika pembelajaran dilakukan di luar kelas (outdoor) yang memberikan pengalaman berbeda kepada anak. Selain itu anak juga mendapatkan kebebasan dan kesempatan yang luas untuk bereksplorasi dan bersosialisasi dengan lingkungan dan teman sebayanya.

Pernyataan tersebut sejalan dengan pendapat (Yuliarto, 2010) yang menyebutkan bahwa kejenuhan pembelajaran di dalam ruang turut memberikan dorongan berkembangnya konsep pendidikan di luar kelas (outdoor learning). Pendidikan dengan metode indoor learning yang bersifat kaku dan formalitas dapat menimbulkan kebosanan dan kejenuhan tehadap rutinitas di sekolah. Metode outdoor learning dijadikan sebagai altenatif baru dalam meningkatkan pengetahuan dalam pencapaian perkembangan khususnya perkembangan fisik motorik anak usia dini.

Layanan pendidikan anak usia dini memfasilitasi pembelajaran yang dirancang khusus untuk anak usia dini yaitu dengan menggunakan model pembelajaran sentra untuk mengembangkan potensi-potensi anak. Model pembelajaran sentra merupakan pengelolaan kelas yang terpusat pada satu kegiatan yang ditangani oleh satu guru sercara khusus. Tujuan diterapkannya sistem sentra ini adalah untuk memudahkan anak dalam proses pembelajaran, tidak tergantung dengan tempat, anak juga dapat belajar berbagai kemampuan dalam satu waktu, bahan-bahan yang mudah didapat, serta dapat dilakukan secara kelompok besar.

Pembelajaran outdoor learning melalui miniatur kegiatan outbound pada sentra bahan alam ini memungkinkan anak melakukan kegiatan yang bervariasi. Kegiatan pada outdoor learning melalui miniatur kegiatan outbound pada sentra 
bahan alam sangat menarik dan cocok bagi anak karena anak dapat menggali kemampuannya untuk mencoba dan berkreasi dengan bahan alam yang telah disediakan oleh guru, selain itu kegiatan di sentra bahan alam juga bervariasi karena terdapat miniatur kegiatan outbound yang sangat menarik bagi anak, khususnya anak usia dini.

(Hurlock, 1980) peningkatan motorik diartikan sebagai unsur kematangan pengendalian gerak tubuh serta otak sebagai pusat gerak. Perkembangan motorik ini secara jelas dibedakan menjadi motorik kasar dan motorik halus. Hal tersebut sejalan dengan pendapat (Santyasa, 2009) yang mengemukakan bahwa perkembangan motorik adalah perubahan perilaku motorik yang memperlihatkan suatu interaksi dari kematangan makhluk dan lingkungannya.

Perkembangan fisik adalah suatu hal yang menjadi dasar untuk kemajuan perkembangan berikutnya. Ketika perkembangan fisik berkembang dengan baik, sangat memungkinkan anak untuk dapat lebih mengembangkan keterampilan fisiknya, serta mengeksplorasi lingkungannya dengan atau tanpa bantuan orang lain. Perkembangan fisik anak ditandai juga dengan berkembangnya kemampuan motorik halus dan motorik kasar (Susanto, 2011).

Sedangkan menurut (Santyasa, 2009) mengemukakan bahwa perkembangan fisik motorik anak cenderung mengikuti pola yang relatif sama sehingga mudah untuk diramalkan, normal atau mengalami hambatan. Meskipun demikian, terdapat perbedaaan laju perkembangan antara anak yang satu dengan anak yang lainnya, sehingga tidak ada individu yang sama persis, baik dalam pertumbuhan fisik maupun perkembangan motoriknya. Perkembangan motorik bergantung pada kematangan 
otot dan saraf sehingga anak akan sulit menunjukkan suatu keterampilan tertentu ketika belum perkembangannya belum matang.

\section{METODE}

Jenis penelitian ini mengacu pada penelitian dan pengembangan (Research and Development). Fokus penelitian adalah untuk mengetahui efektivitas perangkat pembelajaran metode outdoor learning dalam hal mengembangkan aspek fisik motorik anak usia dini khususnya pada usia 5-6 tahun. Produk yang dihasilkan dalam penelitian ini berupa perangkat pembelajaran metode outdoor learning melalui miniatur kegitan outbound dalam upaya mengembangkan aspek perkembangan fisik motorik anak usia dini.

Model pengembangan perangkat pembelajaran yang digunakan dalam penelitian ini adalah menggunakan desain instructional development model 4D yang dikemukakan Thiagarajan yang terdiri dari 4 tahap pengembangan yaitu Define, Design, Develop, dan Disseminate. Secara ringkas rancangan pengembangan perangkat pembelajaran metode outdoor leaning melalui miniatur kegiatan outbound ini dapat digambarkan seperti gambar sebagai berikut: 


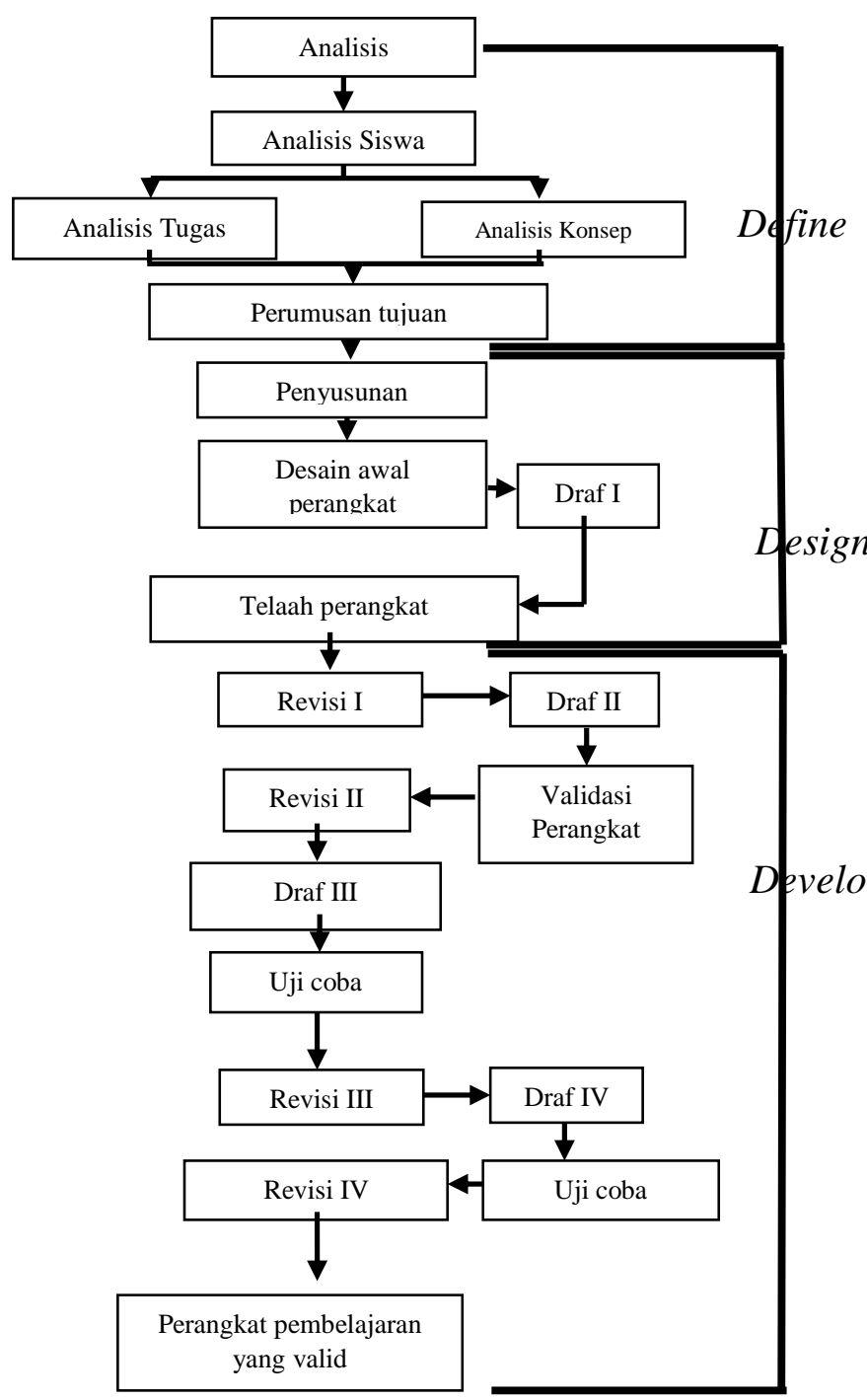

Gambar : pengembangan perangkat pembelajaran metode outdoor leaning

\section{PEMBAHASAN}

Data yang diperoleh dari nilai pre-test dan post-test selanjutnya akan dianalisis melaui uji t Paired Sampel T-test. Teknik analisis ini digunakan untuk mengetahui ada tidaknya pengaruh suatu perlakuan yang dikenakan pada kelompok penelitian tertentu. Hal ini dapat diketahui melalui ada atau tidaknya perbedaan hasil belajar anak sebelum dan sesudah menggunakan perangkat pembelajaran metode outdoor learning. Adapun hipotesis penelitiannya adalah sebagai berikut: 
Ho = Tidak ada perbedaan hasil belajar yang signifikan antara anak kelompok B sebelum menggunakan perangkat pembelajaran metode outdoor learning dengan anak kelompok B sesudah menggunakan perangkat pembelajaran metode outdoor learning.

$\mathrm{Ha}=$ Ada perbedaan hasil belajar yang signifikan antara anak kelompok B sebelum menggunakan perangkat pembelajaran metode outdoor learning dengan anak kelompok B sesudah menggunakan perangkat pembelajaran metode outdoor learning.

Berdasarkan hasil SPSS paired sample statistik dapat diketahui bahwa nilai rata-rata hasil belajar siswa pre-test $59,67<$ post-tets 82,33 maka dapat di katakan bahwa adanya peningkatan hasil belajar sebesar 22,67 setelah belajar menggunakan produk pengembangan perangkat pembelajaran metode outdoor learning pada anak kelompok B.

Berdasarkan hasil analisis SPSS diatas dapat dilihat bahwa signifikasi yang diperoleh adalah 0,000. Hal ini dapat dilihat pada bagian Sig. (2-tailed). Berdasarkan hasil keputusan diketahui jika nilai signifikansi $0,000<0,05$ maka Ho ditolak dan Ha diterima.

\section{Hasil statistik pre-test post-test dengan rumus uji t}

$\mathrm{D}: \frac{680}{30}=22,6$

$$
\begin{aligned}
& \text { Variansi } \begin{aligned}
\left(\mathbf{S}^{2}\right) & =\frac{1}{n-1} \sum_{i-1}^{n} \quad\left(\left(\mathrm{x}^{\mathrm{i}}-\mathrm{x}^{2}\right)-\mathrm{D}\right)^{2} \\
& =\frac{1}{29}(986,8) \\
& =34,02 \\
\text { SD } & =\sqrt{\text { variansi }} \\
& =\sqrt{34,02}
\end{aligned}
\end{aligned}
$$




$$
\begin{aligned}
& \quad=5,83 \\
& \mathrm{t}=\frac{D}{S D} \\
& \sqrt{n} \\
& \mathrm{t}=\frac{22,6}{5,83} \\
& \sqrt{30} \\
& \mathrm{t}=\frac{22,6}{5,47} \\
& \mathrm{t}=4.131 \\
& \mathrm{t}_{\text {hitung }}=4.131 \\
& \mathrm{t}_{\text {tabel }}=2.045
\end{aligned}
$$

Hasil perhitungan dengan menggunakan rumus uji paired sampel t-test diperoleh $t_{\text {hitung }}=4.131$ dan $t_{\text {tabel }}=2.045$. Karena $t_{\text {hitung }}>t_{\text {tabel }}$ maka Ho ditolak dan Ha diterima.

Berdasarkan hasil SPSS dan rumus manual uji paired sampel t-test menunjukkan bahwa Ha diterima, sehingga dapat dibuktikan bahwa ada perbedaan hasil belajar yang signifikan antara anak kelompok B sebelum menggunakan perangkat pembelajaran metode outdoor learning dengan anak kelompok B sesudah menggunakan perangkat pembelajaran metode outdoor learning.

Analisis Tingkat Keefektivitasan Perangkat Pembelajaran Metode Outdoor Learning Untuk Mengembangkan Aspek Fisik Motorik Anak Usia Dini

Pembelajaran yang efektif menurut Popham dan Baker dalam Suyanto adalah pembelajaran yang terjadi jika guru dapat mengubah kemampuan dan presepsi anak dari yang sulit menjadi mudah untuk dipelajari. Ada beberapa hal supaya pembelajaran yang dilakukan dapat diakatakan efektif diantaranya yaitu 1) Adanya analisis kebutuhan anak dengan cara menganalisis kemampuan dan harapan anak 
dari proses pembelajaran. 2) Harus ada gambaran mengenai evaluasi yang dipakai dalam pembelajaran.

Tingkat efektifitas pada perangkat pembelajaran yang dikembangkan diukur dari nilai anak sebelum dan sesudah menggunakan perangkat pembelajaran metode outdoor learning. Selain itu keefektifan modul perangkat pembelajaran juga dinilai dari angket yang telah diberikan kepada Guru pembelajaran.

Pemerolehan hasil belajar berdasarkan uji lapangan yang diukur melalui nilai rata-rata hasil post-test sebesar 82,33 yang lebih meningkat dari pada rata-rata hasil pre-test 59,67. Peningkatan hasil belajar anak mencapai 22,67 setelah menggunakan perangkat pembelajaran metode outdoor learning. Merujuk pada hasil yang diperoleh dari analisis SPSS 25, nilai signifikansi yang diperoleh adalah 0,000 yang berarti kurang dari 0,05 sehingga dapat diperoleh kesimpulan bahwa ada perbedaan yang signifikan antara rata-rata hasil belajar anak sebelum dan sesudah menggunakan perangkat pembelajaran metode outdoor learning.

\section{KESIMPULAN}

Hasil validasi menunjukkan bahwa perangkat pembelajaran metode outdoor learning melalui miniatur kegiatan outbound memiliki tingkat kevalidan materi sebesar 93\%,tingkat kevalidan bahasa sebesar $85,71 \%$, dan tingkat kevalidan ahli pembelajaran sebesar 94,64\%.

Perolehan hasil belajar berdasarkan uji lapangan yang diukur menggunakan tes pencapaian hasil belajar setelah dianalisis menunjukkan: Rata-rata perolehan hasil belajar pada kelompok ekperimen mengalami peningkatan perolehan dari perolehan nilai awal (pre-test) 59,67 dan meingkat menjadi 82,33 (post-test), 
Sehingga dapat diketahui adanya peningkatan hasil belajar sebesar 22,67. Hasil rata-rata kemudian dianalisis menggunakan uji hipotesis dalam penelitian dengan menggunakan paired sampel test. Dari uji paired sampel test memperoleh nilai signifikansi sebesar $0,000<0,05$ sehingga dapat diketahui bahwa Ho di tolak dan Ha di terima.

Berdasarkan uraian diatas maka dapat disimpulkan secara umum bahwa perangkat pembelajaran metode outdoor learning melalui miniatur kegiatan outbound secara umum memiliki tingkat efektifitas yang baik untuk mengembangkan aspek fisik motorik anak usia dini.

Saran yang dapat peneliti sampaikan yaitu Perangkat pembelajaran metode outdoor learning melalui miniatur kegiatan outbound yang telah dikembangkan masih banyak yang belum mengetahu, maka dari itu hendaknya guru lebih menggali metode yang tepat digunakan untuk mengembangkan semua aspek pada anak khususnya aspek fisik motorik anak. Kedua, Penggunaan perangkat pembelajaran metode outdoor learning melalui miniatur kegiatan outbound ini jika digunakan sebaiknya guru mempersiapkan alat permainan edukatif yang bisa digunakan sebagai penunjang pemerolehan konsep dan materi agar pembelajaran menjadi lebih bermakna dan meningkatkan perkembangan anak. 


\section{RUJUKAN}

Ancok, Djamaludin. 2002. Outbound Management Training. Yogjakarta: UII Press Yogjakarta.

Arikunto. 2006. Prosedur Penelitian Suatu Pendekatan Praktik. Jakarta: Rhineka Cipta

Asmawati, Luluk. 2008. Pengelolaan Kegiatan Pengembangan Anak Usia Dini. Jakarta: Universitas Terbuka.

Badiatul, Muchisin Asti. 2009. Fun Outbound-Merancang Kegiatan Outbound yang Efektif. Yogjakarta: Diva Press.

Bilton, Hellen. 2005. Learning Outdoor "Improving the Quality of Young Children Play Outdoor”. London: David Fulton Publisher.

Hurlock. 1980. Psikologi Perkembangan Suatu Pendekatan Sepanjang Rentang Kehidupan (terj.). Jakarta: Erlangga.

Husamah. 2013. Pembelajaran Luar Kelas Outdoor Learning. Jakarta: Prestasi Pustaka.

Santyasa, I. W. 2009. Pembelajaran Berbasis Masalah dan Pembelajaran Kooperatif. Jakarta: Departemen Pendidikan Nasional.

Sugiyono. 2010. Metode Penelitian Pendidikan (Pendekatan Kuantitatif, Kualitatif, dan $R \& D)$. Bandung: Alfabeta.

Sujiono, Yuliani Nurani. 2009. Konsep Dasar pendidikan Anak Usia Dini. Jakarta: Indeks.

Susanto, Ahmad. 2011. Perkembangan Anak Usia Dini; Pengantar dalam Berbagai Aspeknya. Jakarta: Kencana.

Suyanto, Slamet. 2005. Konsep Dasar Pendidikan Anak Usia Dini. Jakarta: Depdiknas.

Santyasa, I. W. 2009. Pembelajaran Berbasis Masalah dan Pembelajaran Kooperatif. Jakarta: Departemen Pendidikan Nasional.

Sugiyono. 2010. Metode Penelitian Pendidikan (Pendekatan Kuantitatif, Kualitatif, dan $R \& D)$. Bandung: Alfabeta.

Sujiono, Yuliani Nurani. 2009. Konsep Dasar pendidikan Anak Usia Dini. Jakarta: Indeks. 
Susanto, Ahmad. 2011. Perkembangan Anak Usia Dini; Pengantar dalam Berbagai Aspeknya. Jakarta: Kencana.

Suyanto, Slamet. 2005. Konsep Dasar Pendidikan Anak Usia Dini. Jakarta: Depdiknas. 